\title{
The Triangular Relationship Between Nationality, EU Citizenship and Migration in EU Law: A Tale of Competing Competences
}

\section{Helen Oosterom-Staples ${ }^{1}$}

Published online: 30 November 2018

(c) The Author(s) 2018

\begin{abstract}
Within the legal framework of the EU, the Member States have remained competent to regulate who qualifies as a national. As nationals of a Member State are simultaneously EU citizens and enjoy the right to intra-EU mobility, it is the Member States who, through their Nationality Laws, determine who is to be classed as an EU citizen and who enjoys the right to intra-EU mobility. This article explores whether Member State competence to regulate nationality matters has been affected by the introduction of EU citizenship and/or developments in intra-EU mobility rights, the contents of which are determined primarily by the EU.
\end{abstract}

Keywords EU citizen · EU citizenship - Intra-EU mobility · EU Member States · Conferral · Acquisition nationality $\cdot$ IIPs $\cdot$ Loss nationality $\cdot$ Dual nationality · Minors $\cdot$ Brexit

\section{Introduction}

In 1992 O'Leary $^{1}$ labelled the relationship between Nationality Law and EU citizenship one of two uneasy bedfellows, because the personal scope of EU citizenship is defined in terms of nationality of a Member State. ${ }^{2}$ As 'the right to move to and reside in an EU Member State of which the EU citizen is not a national' is one of the rights attached to the status of EU citizen, nationality also determines the beneficiaries of the right to intra-EU mobility. ${ }^{3}$ Underlying this metaphor is the division of competences between

\footnotetext{
1 O'Leary (1992), p. 353.

2 See Art. 20(1) of the Treaty on the Functioning of the European Union (TFEU).

3 'Intra-EU mobility rights' is used as a shorter alternative to 'the right to move and reside in a Member State of which the EU citizen is not a national'. As it is used in this contribution, it includes both the legal framework for intra-EU mobility set out in Directive 2004/38/EC of the European Parliament and
}

Helen Oosterom-Staples

h.oosterom@tilburguniversity.edu

1 Tilburg University, Tilburg, The Netherlands 
the European Union (EU) and its Member States in the areas of EU citizenship, nationality and intra-EU mobility (rights). Similar observations concerning the division of competence between the EU and its Member States in these areas of EU law have been made by other scholars. In 1991 Evans, for instance, noted that it 'would be illogical' if Member States can determine the beneficiaries of intra-EU mobility rights unilaterally through the definition of nationality in their Nationality Law if the contents of intra-EU mobility rights are to be determined unilaterally by the EU. ${ }^{4}$

These observations must be considered in the light of the settled case law of the Court of Justice of the EU (further: Court of Justice) defining the key concepts which form the parameters of intra-EU mobility. According to this case law, the contents of these concepts are defined exclusively by the Court of Justice as this is the only way to ensure uniform application of intra-EU mobility rules in all Member States. Uniformity ensures that the level of protection enjoyed according to intra-EU mobility rules does not depend on the Member State where these rules are invoked. In the words of the Court of Justice: Member States cannot 'eliminate at will the protection afforded by the Treaty to certain categories of person'. 5 The paradox is, therefore, that Member States, as sovereign States, determine who the beneficiaries of intra-EU mobility rights are, and that the EU determines the contents of those rights. What both scholars effectively question is whether the nature of Member State competence to determine the beneficiaries of intra-EU mobility would change after intra-EU mobility had been allotted the status of EU citizenship right.

The work of both scholars predates the introduction of EU citizenship in 1993. Any observations made by them regarding the relationship between nationality and EU citizenship were therefore speculative by nature. 25 years have passed since the introduction of EU citizenship. It is therefore time to evaluate how the relationship between nationality, EU citizenship and intra-EU mobility has developed since then. Has the introduction of EU citizenship changed the right to intra-EU mobility, as anticipated by scholars? Has the nature of Member State competence to determine who their nationals are changed because nationality is the only condition to qualify as an EU citizen? Have Member States and/or the EU institutions responded to amendments made by Member States to their Nationality Law? Can these responses be attributed to concerns regarding the obligations which intra-EU mobility rules impose on authorities of these Member States?

To answer these questions Sect. 2 will provide a concise outline of the principle of conferral and the nature of competences as they govern and determine the relationship between the EU and its Member States in general and in nationality

\footnotetext{
Footnote 3 (continued)

of the Council of 29 April 2004 on the right of citizens of the Union and their family members to move and reside freely within the territory of the Member States (further: Directive 2004/38/EC or Residence Directive) [2004] OJ 2004 L 229/35, as amended, see: [2005] OJ L 30/27 and the right to move and reside in Arts. 20(2)(a) and 21(1) TFEU, as developed by the Court of Justice in its case law.

4 Evans (1991), p. 191.

5 ECJ 19 March 1964, Case 75/63, Mrs M.K.H. Hoekstra (née Unger)/Bestuur der Bedrijfsvereniging voor Detailhandel en Ambachten, ECLI:EU:C:1964:19.
} 
and intra-EU mobility matters in particular. This section will also provide a concise outline of EU citizenship and intra-EU mobility to the extent that this is necessary to understand the examples which will be discussed in Sect. 3. The examples discussed in Sect. 3 have been selected because they shed some light on how Member States and/or the EU (institutions) have responded to developments in the areas of EU citizenship, intra-EU mobility and nationality. Do these examples justify the conclusion that EU citizenship and/or intra-EU mobility have curtailed Member State competence to regulate nationality? Has Member State competence to regulate nationality impacted on the development of EU citizenship and/or intra-EU mobility? Moving beyond the interaction between these three concepts and the responses of the various actors, Sect. 4 reflects on the challenges to the relationship between nationality, EU citizenship and intra-EU mobility which now face the Member States and the EU alike. To be more precise, the implications of the withdrawal of a Member State from the EU for the status of and rights accorded to EU citizens on termination of one Member State's EU membership; a scenario that was not considered nor provided for by EU law in 1993 when the status of EU citizenship was introduced.

\section{Painting the Legal Landscape}

\subsection{The Principle of Conferral and Sincere Cooperation}

As any international organisation, the EU can only act if its Member States have conferred competences on it. ${ }^{6}$ In the context of EU law 'conferred' means that 'the Union shall act only within the limits of the competences conferred upon it by the Member States in the treaties to attain the objectives set out therein'. ${ }^{7}$ Whether and to what extent the EU legislator can regulate a specific policy area can be ascertained by consulting the catalogue of competences in Articles 3-6 TFEU. The EU's competences are categorised as 'exclusive', 'shared', 'coordinating' and 'supporting, coordinating and supplementing Member State action'. Competences that have not been conferred on the EU are those not listed in Articles 3-6 TFEU. They remain with the Member States and are referred to as an exclusive Member State competence. ${ }^{8}$

Nationality is a prime example of an exclusive Member State competence. The EU legislator cannot regulate in an area that is designated an exclusive Member State competence. However, years of cooperation have meant that both legal orders have become so intertwined, that an exclusive Member State competence cannot be separated from an EU competence. In policy areas that have become so closely knitted as intra-EU mobility and nationality are, it is inevitable that any change introduced by a Member State in an area that belongs to its exclusive competence impacts on an area that belongs to the EU's competences. As a means to police this interaction between competences the Court of Justice has held time and again that

\footnotetext{
${ }^{6}$ See on the principle of conferral within the context of the EU: Barnard and Peers (2017), pp. 105-110.

7 Art. 5(2) Treaty on European Union (TEU).

8 Art. 4(1) TEU.
} 
when a Member State exercises an exclusive Member State competence, it may not frustrate the EU's policies and objectives. If it does, this is classed as a breach of the principle of Union loyalty or sincere cooperation. Depending on the circumstances, the principle of Union loyalty obliges Member States to either assist the EU in carrying out its tasks, as set out in the Treaties; take all appropriate measures to fulfil the obligations which are imposed on them by virtue of EU law; or refrain from acting if by acting they could jeopardise the realisation of the EU's objectives. ${ }^{9}$

'Exclusive EU competence' denotes the situation in which only the EU legislator may adopt legally binding acts. Even if the EU legislator fails to regulate a certain issue, 'exclusive EU competence' means that Member States cannot regulate in that particular policy area. There are two exceptions to this rule. Firstly, Member States can act if they have been explicitly authorised to do so by the EU. Secondly, Member States can act if national implementation measures are necessary to give effect to an EU measure. ' ${ }^{10}$ 'Shared competence' means that both the EU and the Member States may regulate and adopt legally binding acts in a policy area designated as a shared competence. The scope for Member State action in areas of shared competence is ring-fenced as followed. Once the EU legislator has exercised its competence, Member States can only 'exercise their competence to the extent that the Union has not exercised its competence'. ${ }^{11}$ If the EU legislator refrains from exercising its competence or decides to cease to exercise it, Member States may (re)assume their role as legislator, subject to the principle of Union loyalty.

Intra-EU mobility, one of the so-called 'four freedoms' to be developed within the context of the Internal Market, is a shared competence. ${ }^{12}$ The broad reading given by the Court of Justice to intra-EU mobility rights has curtailed Member State competence $^{13}$ to the extent that they cannot unilaterally determine the meaning or contents of the concepts used in this area of EU law. ${ }^{14}$ Entry and residence conditions are exhaustive, meaning that no other or additional conditions can be imposed on those exercising their rights than those provided for by EU law. ${ }^{15}$ Where entry

\footnotetext{
9 Art. 4(3) TEU. For criminal law, see, for instance: ECJ 24 November 1998, Case C-274/96, Horst Otto Bickel, Ulrich Franz, ECLI:EU:C:1998:563, para. 17.

10 Art. 2(1) TFEU.

11 Art. 2(2) TFEU.

12 Art. 4(2)(a) TFEU.

13 ECJ (Fifth Chamber) 29 April 2004, Case C-482/01, Georgios Orfanopoulos a.O. and Raffaele Oliveri/Land Baden-Württemberg, ECLI:EU:C:2004:262, para. 64.

14 ECJ 4 December 1974, Case 41/74, Yvonne van Duyn/Home Office, ECLI:EU:C:1974:133, para. 18; ECJ 27 October 1977, Case 30/77, Regina/Pierre Bouchereau, ECLI:EU:C:1977/172, para. 33; Orfanopoulos and Oliveri, above n. 13, para. 65; ECJ (First Chamber) 27 April 2006, Case C-441/02, Commission/Germany, ECLI:EU:C:2006:253, para. 34; ECJ (Third Chamber) 7 June 2007, Case C-50/06, Commission/the Netherlands, ECLI:EU:C:2007:325, para. 42; CJEU (Grand Chamber) 13 September 2016, Case C-165/14, Alfredo Rendón Marín/Administración del Estado, ECLI:EU:C:2016:675, paras. 58 and 82; CJEU (Grand Chamber) 13 September 2016, Case C-304/14, Secretary of State for the Home Department/CS, ECLI:EU:C:2016:674, para. 37.

15 ECJ (Grand Chamber) 25 July 2008, Case C-127/08, Blaise Baheten Metock and Others/Minister for Justice, Equality and Law Reform, ECLI:EU:C:2008:449, para. 53. See also: ECJ (Second Chamber) 14 April 2005, Case C-157/03, Commission/Spain, ECLI:EU:C:2005:225, paras. 29-31 and Conclusion
} 
and residence conditions are satisfied, by operation of law, ${ }^{16}$ there is a right to enter and reside in a Member State of which an EU citizen is not a national. ${ }^{17}$ The mirror image is that a Member State can only revoke or end intra-EU mobility rights if this is justified by concerns related to public policy, national security or national health. As key determinants of intra-EU mobility rights, the Court of Justice has interpreted these derogations to the fundamental right to intra-EU mobility strictly. The status $q u o$ is that Member States cannot determine their contents unilaterally. ${ }^{18}$ National courts, guided by the Court of Justice, monitor if Member State authorities have exercised their discretionary powers in an individual case as provided for by EU law. ${ }^{19}$ So even if Member States hold the key to intra-EU mobility, they have little power to determine the contents of the right to intra-EU mobility. The situation for the EU is the reverse. The EU might be the one determining the contents of intra-EU mobility rights it has no say in who benefits from those rights.

\subsection{Nationality, EU Citizenship and Intra-EU Mobility}

The fact that nationality is an exclusive Member State competence does not mean that, as a concept, it is not found in the Treaties. On the contrary, nationality is used to determine who qualifies as EU citizen. ${ }^{20}$ In the context of intra-EU mobility, it not only determines the beneficiaries of intra-EU mobility, but also curtails Member State competence to adopt legislation that would allow them to treat nationals of other Member States as second class citizens. ${ }^{21}$ The principle of non-discrimination has been developed into a tool that protects EU citizens exercising their right to intra-EU mobility from becoming a 'second class citizen' in a Member State

\footnotetext{
Footnote 15 (continued)

of Advocate General Poiares Maduro of 3 April 2008 in Case C-524/06, Heinz Huber/Bundesrepublik Deutschland, ECLI:EU:C:2008:194, para. 13.

${ }^{16}$ ECJ 8 April 1976, Case 48/75, Jean Noël Royer, ECLI:EU:C:1976:57, para. 33; ECJ 25 July 2002, Case C-459/99, MRAX/Belgian State, ECLI:EU:C:2002:461, para. 74; ECJ (Grand Chamber) 23 March 2006, Case C-408/03, Commission/Belgium, ECLI:EU:C:2006:192, paras. 62-65; CJEU (Third Chamber) 21 July 2011, Case C-408/03, Secretary of State for Work and Pensions/Maria Dias, ECLI:EU:C:2011:498, paras. 48-49.

${ }^{17}$ ECJ17 September 2002, Case C-413/99, Baumbast, R/Secretary of State for the Home Department, ECLI:EU:C:2002:49, paras. 84-86.

${ }_{18}$ See: ECJ 3 June 1992, Case C-360/89, Commission/Italy, ECLI:EU:C:1992:235, paras. 13-14.

19 ECJ 26 February 1975, Case 67/74, Carmelo Angelo Bonsignore/Oberstadtdirektor der Stadt Köln, ECLI:EU:C:1975:34, para. 7, ECJ 28 October 1975, Case 36/75, Roland Rutili/Ministre de l'intérieur, ECLI:EU:C:1975:137, para. 29; Royer, above n. 16, para. 46; ECJ 18 May 1982, Joined Cases 115/81116/81, Rezguia Adoui/Belgian State and City of Liège; Dominique Cornuaille v. Belgian State, ECLI:EU:C:1982:183, para. 11; ECJ 10 February 2000, Case C-340/97, Ömer Nazli a.O./Stadt Nürnberg, ECLI:EU:C:2000:77, paras. 59 and 63; ECJ 26 November 2002, Case C-100/01, Ministre de l'Intérieur/Aitor Oteiza Olazabal, ECLI:EU:C:2002:712, paras. 30-32.

${ }^{20}$ Art. 9 TEU and Art. 20(1) TFEU.

${ }^{21}$ Art. 18 TFEU. For intra-EU mobility, see the following lex specialis: Art. 45 TFEU and Art. 7(2) Regulation (EU) No. 492/2011 of the European Parliament and of the Council of 5 April 2011 on Freedom of Movement for Workers within the Union (codification) [2011] OJ L 141/1 and Art. 24 Directive 2004/38/EC.
} 
of which they are not a national, the so-called host Member State. The principle of non-discrimination has been developed by the Court of Justice to capture both national laws that are either directly discriminatory, indirectly discriminatory or operate as an obstacle when exercising intra-EU mobility rights. So, a national rule that uses nationality as qualifying condition has to be set aside as it differentiates between the own nationals and nationals of other Member States and is, therefore, incompatible with EU law. The same holds true for Member State legislation that is indirectly discriminatory, meaning that nationality as such is not used as qualifying condition, but rather another condition which own nationals, as a rule, will find easier to satisfy than nationals of other Member States. Examples of qualifying conditions that amount to indirect discrimination are: place of education or residence and language skills. National laws which are capable of impeding the exercise of intraEU mobility rights are classed as obstacles to intra-EU mobility. The prime example of a rule that is an obstacle to intra-EU mobility in the Court of Justice's case law is the transfer sums that have to be paid if a football player wishes to change clubs before the end of his contract. As a professional footballer cannot change clubs until the transfer negotiations between the old and the new club have been completed and the transfer sum paid, this effectively bars him from being employed by a new club. Where the old and the new club are located in two different Member States, this means that a footballer seeking employment in another Member State cannot exercise his intra-EU mobility right until agreement is reached between his old club and a new club on the terms of his transfer from one club to the other. ${ }^{22}$ Like any rule of EU law, compliance with the principle of equal treatment is ensured through the principles of supremacy and direct effect. These principles require Member States to set aside any national law at odds with the principle of equal treatment if they cannot provide an objective justification for the rule or where the rule does not pass the EU's proportionality test. ${ }^{23}$

Whereas intra-EU mobility has been part and parcel of EU law since 1957, EU citizenship was not introduced until 1993. The idea was that by according the status of EU citizen to the nationals of the Member States this would 'bring the Union closer to its citizens'. ${ }^{24}$ EU citizen is defined as '[e]very person holding the nationality of a Member State'. ${ }^{25}$ According to the Court of Justice's settled case law EU citizenship is 'destined to be the fundamental status of nationals of the Member

\footnotetext{
22 ECJ 15 December 1995, Case C-415/93, Union royale belge des sociétés de football association ASBL/Jean-Marc Bosman, Royal club liégeois SA/Jean-Marc Bosman a.O. and Union des associations européennes de football (UEFA)/Jean-Marc Bosman, ECLI:EU:C:1995:463, paras. 92-104. See also: CJ EU (Grand Chamber) 16 March 2010, Case C-325/08, Olympique Lyonnais SASP/Olivier Bernard and Newcastle UFC, ECLI:EU:C:2010:143, paras. 33-37. For an excellent analysis of the operation of the principle of equal treatment, see: Nic Shuibhne (2013), Chapters 6 and 7.

23 ECJ 15 July 1964, Case 6/64, Flaminio Costa/E.N.E.L, ECLI:EU:C:1964:66; ECJ 5 February 1963, Case 26/92, NV Algemene Transport- en Expeditie Onderneming van Gend \& Loos/Netherlands Inland Revenue Administration, ECLI:EU:C:1963:1.

24 Spanish Memorandum, 'Towards a European Citizenship', Europe Documents No. 1653, 2 October 1990 .

25 Art. 9 TEU and Art. 20(1) TFEU.
} 
States'. ${ }^{26}$ It is 'additional to and [does] not replace national citizenship' ${ }^{27}$ This means that a national of a Member State is simultaneously a citizen of that State and an EU citizen.

Like citizenship of a nation-State, EU citizenship comes with rights. ${ }^{28}$ It differs-and is criticized for this very reason-from national citizenship because there are no duties attached to it. ${ }^{29}$ Intra-EU mobility, as EU citizenship right, has developed into the right that is fundamental to EU citizenship. ${ }^{30}$ It is conferred directly on an EU citizen, albeit subject to 'the limitations and conditions laid down by the [TFEU] and by the measures adopted to give it effect'. ${ }^{31}$ Effectively this means that it does not differ from the traditional right to intra-EU mobility, as developed since the founding of the European Economic Community (EEC) in 1957. From this perspective the added value of according intra-EU mobility the status of EU citizenship right can be questioned. Does the status of EU citizenship right mean that the gaps in protection which are inherent to intra-EU mobility will be filled, meaning that intra-EU mobility is a true right, rather than a paper one for every EU citizen ${ }^{32}$

The conditions and limitations subject to which EU citizens enjoy the right to intra-EU mobility are currently set out in the so-called Residence Directive. ${ }^{33}$ One of the objectives of this Directive, as follows from its recital 4, is to 'facilitate and strengthen the exercise of the primary and individual right-conferred directly on all Union citizens by the Treaty-to move and reside freely within the territory of the Member States [emphasis added]. ${ }^{34}$ The Residence Directive has replaced the fragmented, hence complex, legal framework that has been developed since the mid1960s in the context of the Internal Market and has codified the Court of Justice's case law on intra-EU mobility under the 'old' law. ${ }^{35}$ Its very foundations are therefore the same as those which underpinned intra-EU mobility prior to the introduction of EU citizenship. This, in particular, holds true for the so-called 'inter-State link' that restricts the territorial application of the Residence Directive to 'the Member State of which an EU citizen is not a national'. ${ }^{36}$ This is not a problem for the EU

\footnotetext{
${ }^{26}$ ECJ 20 September 2001, Case C-184/99, Rudy Grzelczyk and Centre public d'aide sociale d'Ottignies-Louvain-la-Neuve, ECLI:EU:C:2001:458, para. 31.

27 Art. 9 TEU and Art. 20(1) TFEU.

${ }^{28}$ For a list of these rights, see: Art. 20(2) TFEU.

29 Kochenov (2014) and Nic Shuibhne (2015).

30 Raucea (2016), p. 488.

31 Baumbast, above n. 17, paras. 84-85.

32 See: Oosterom-Staples and Vasquez Munoz (2004).

33 CJEU (Third Chamber) 19 September 2013, Case C-140/12, Pensionsversicherungsanstalt/Peter Brey, ECLI:EU:C:2013:565, para. 53. With reference to: CJEU (Third Chamber) 5 May 2011, Case C-434/09, Shirley McCarthy/Secretary of State for the Home Department, ECLI:EU:C:2011:277, para. 3; CJEU (Grand Chamber) 21 December 2011, Joined Cases C-424/10 and C-425/10, Tomasz Ziolkowski and Barbara Szeja and Others/Land Berlin, ECLI:EU:C:2011:866, paras. 36 and 40.

34 Brey, above n. 33, para. 53. With reference to: Metock, above n. 15, paras. 82 and 59; CJEU (Third Chamber) 7 October 2010, Case C-162/09, Secretary of State for Work and Pensions/Taous Lassal, ECLI:EU:C:2010:592, para. 30; Shirley McCarthy, above n. 33, para. 28.

35 Art. 40(1) Directive 2004/38/EC.

36 Art. 3(1) Directive 2004/38/EC.
} 
citizen himself. By virtue of his nationality, an EU citizen enjoys an unconditional right to remain in that Member State under international law, ${ }^{37}$ namely Article 3 of Protocol No. 4 to the 1950 Convention for the Protection of Human Rights and Fundamental Freedoms. ${ }^{38}$ How different is the situation for his family members who are not nationals of a Member State, so-called third-country nationals. As family members enjoy derived rights under the Residence Directive, they are only protected by that Directive in the Member State where the EU citizen exercises intra-EU mobility rights. ${ }^{39}$ How the Court of Justice has addressed so-called purely internal situations and what the implications of this case law are for Member State competence in nationality matters will be considered in Sects. 3.3.2 and 3.4.

\subsection{Nationality; A Controversial Concept in EU Law}

As said, 'nationality' is used in the EU's Treaties to define who qualifies as EU citizen. The status of EU citizen was introduced by the Treaty of Maastricht when it entered into force on 1 November 1993. The choice to use nationality as qualifying condition received a sceptical welcome by Member States, fearing an erosion of national citizenship, as the following illustrates. ${ }^{40}$ To obtain Danish approval of the Maastricht Treaty, the Heads of State and Government meeting as the European Council on 11 and 12 December 1992 adopted the following Decision on EU citizenship:

The provisions of Part Two of the Treaty establishing the European Community relating to citizenship of the Union give nationals of the Member States additional rights and protection as specified in that Part. They do not in any way take the place of national citizenship. The question whether an individual possesses the nationality of a Member State will be settled solely by reference to the national law of the Member State concerned. ${ }^{41}$

\footnotetext{
${ }^{37}$ ECJ 7 July 1992, Case C-237/90, The Queen/Immigration Appeal Tribunal and Surinder Singh, ex parte Secretary of State for the Home Department, ECLI:EU:C:1992:296, para. 22; ECJ (Grand Chamber) 11 December 2007, Case C-291/05, Minister voor Vreemdelingenzaken en Integratie/RNG Eind, ECLI:EU:C:2007:771, para. 31; Shirley McCarthy, above n. 33, para. 29; CJEU (Grand Chamber) 14 November 2017, Case C-165/16, Toufik Lounes/Secretary of State for the Home Department, ECLI:EU:C:2017:862, para. 37.

${ }^{38}$ ETS No. 46.

39 ECJ (First Chamber) 8 July 1992, Case C-243/91, Belgian State/Noushin Taghavi, ECLI:EU:C:1992:306, para. 7; ECJ (Grand Chamber) 11 December 2007, Case C-291/05, Minister voor Vreemdelingenzaken en Integratie/RNG Eind, ECLI:EU:C:2007:771, para. 23; Shirley McCarthy, above n. 33, para. 42; CJEU (Grand Chamber) 12 March 2014, Case C-456/12, O/Minister voor Immigratie, Integratie en Asiel, and Minister voor Immigratie, Integratie en Asiel/B, ECLI:EU:C:2014:135, paras. $42-43$.

${ }^{40}$ Closa (1994), p. 115.

${ }^{41}$ Decision of the Heads of State and Government, Meeting within the European Council, Concerning Certain Problems Raised by Denmark on the Treaty on European Union, Annex I [1992] OJ C 348/2, Section A.
} 
This Decision was annexed to the Danish Act of Ratification and paved the way for Danish approval of the Maastricht Treaty. Danish approval came with a declaration confirming the complementary nature of EU citizenship and spelling out exclusive Danish competence to determine who is eligible for Danish nationality. ${ }^{42}$ In 1999 the Treaty of Amsterdam incorporated the contents of the Decision on EU citizenship in what is now Article 20(1) TFEU as follows: 'Citizenship of the Union shall complement and not replace national citizenship'. This amendment to what is now Article 20(1) TFEU meant that, from the entry into force of the Treaty of Amsterdam, the complementary nature of EU citizenship was spelled out for all Member States that, under the Decision on EU citizenship, had been a Danish prerogative.

The Decision on EU citizenship is not the only evidence of Member State concern regarding their competence in nationality matters pending the introduction of EU citizenship. The exclusive nature of Member State competence to determine unilaterally who their nationals are was spelled out in the Declaration on Nationality of a Member State. This Declaration that was annexed to the Final Act of the Treaty on European Union $^{43}$ when that Treaty entered into force in 1993, reads as follows:

The Conference declares that, wherever in the Treaty establishing the European Community reference is made to nationals of the Member States, the question whether an individual possesses the nationality of a Member State shall be settled solely by reference to the national law of the Member State concerned. Member States may declare, for information, who are to be considered their nationals for Community purposes by way of a declaration lodged with the Presidency and may amend any such declaration when necessary. ${ }^{44}$

The purpose of the Declaration on Nationality of a Member State was to provide clarity on 'the definition of the ambit ratione personae of the provisions of European Union law referring to the concept of national'. In the Rottmann case, ${ }^{45}$ the Court of Justice held that the Decision on EU citizenship and the Declaration on Nationality are instruments that have to be taken into consideration when establishing the personal scope of EU law. These Declarations are not, however, the only instruments that determine the personal scope of the right to intra-EU mobility.

\subsection{Declarations on Member State Nationality}

As claims to intra-EU mobility rights are made in the Member States of which an EU citizen is not a national, accession to and amendments introduced by a Member

\footnotetext{
${ }^{42}$ Unilateral Declarations of Denmark, to be Associated to the Danish Act of Ratification of the Treaty on European Union and of which the Eleven other Member States will take Cognizance [1992] OJ C $348 / 4$.

43 According to Art. 51 TEU 'Protocols and Annexes to the Treaties [...] form an integral part thereof'.

${ }^{44}$ Declaration No. 2 on Nationality of a Member State, annexed to the Treaty on European Union by the Treaty of Maastricht.

${ }^{45}$ CJEU (Grand Chamber) 2 March 2010, Case C-135/08, Janko Rottmann/Freistaat Bayern, ECLI:EU:C:2010:104, para. 40.
} 
State to its Nationality Law post accession ${ }^{46}$ change the number of claims to intraEU mobility that can be expected by other Member States. A new Member State means that all the nationals of that State are entitled to claim rights under the intraEU mobility scheme in the 'old' Member States. Likewise, more lenient or restrictive conditions to obtain or lose the nationality of a Member State determine who qualifies as a national of that Member State and, as a national of that Member State can claim intra-EU mobility rights in other Member States. To help the other Member States to identify their nationals who have to be treated as beneficiaries of intraEU mobility rights, Germany and the UK adopted Declarations on nationality at the time of their accession to the then European Economic Community.

The following, seemingly simple declaration albeit one with far-reaching consequences, was made in 1957 by the Government of the Federal Republic of Germany at the time of its signature of the Treaty establishing the European Economic Community and the Treaty establishing the European Atomic Energy Community:

All Germans as defined in the Basic Law for the Federal Republic of Germany shall be considered nationals of the Federal Republic of Germany. ${ }^{47}$

According to the definition of 'German' in Article 116 of Germany's Basic Law at the time that this declaration was made, the declaration covered the German citizens of both the German Democratic Republic and the Federal Republic of Germany alike. The effect of the German declaration was felt on 3 October 1990, the day of the reunification of the German Democratic Republic and the Federal Republic of Germany. From this day onwards, the other Member States had to treat all nationals of the former German Democratic Republic as beneficiaries of intra-EU mobility rights. ${ }^{48}$ With no prior intervention by the Member States or the EU institutions, the reunification of the two Germanys meant that the approximately 18 million nationals of the former German Democratic Republic were transformed into nationals of a Member State, entitled to intra-EU mobility.

The declaration deposited by the UK on its accession to the then EEC (the 1972 Declaration ${ }^{49}$ ) was replaced by a new Declaration in 1982 reflecting an amendment to the British Nationality Act taking effect on 1 January 1983 (the 1982 Declaration). ${ }^{50}$ Whereas the German Declaration is inclusive by nature, this is not the case for the UK's Declarations. Both declarations categorize UK citizens according to their place of birth in the Commonwealth and then accord the right to intra-EU mobility to citizens who were born in the UK. The other Member States did not actually go as far as to challenge the legality of both UK Declarations. They did, however, append a Joint Declaration on Free Movement of Workers to the UK's Act of Accession, reserving the right to seek EU intervention if-what they considered

\footnotetext{
${ }^{46}$ Evans and Jessurun d'Oliveira (1991), p. 306.

47 Available at https://eur-lex.europa.eu/legal-content/EN/TXT/?qid=1531822091269\&uri=CELEX :11957E/AFI/DCL/DEFAL (accessed 29 October 2018).

48 De Groot (2004), p. 10 and Jessurun d'Oliveira (1999), pp. 402-410.

49 [1972] OJ L 73/196.

50 [1983] OJ C 23/1.
} 
to be- the broad definition of national in the 1972 Declaration on Nationality meant that one or more Member States found itself in a difficult social situation as a direct result of the application of the provisions governing free movement of workers. ${ }^{51}$

The UK's Declarations were subject of scrutiny by the Court of Justice when challenged by Ms Kaur in 2001. Ms Kaur claimed that the UK had not observed fundamental rights when adopting them as she, a Commonwealth citizen, had been relegated to the ranks of 'British Overseas Citizen' with neither a right of abode in the UK, nor a right to intra-EU mobility. The Court of Justice qualified the 1972 Declaration 'as an instrument relating to the Treaty for the purpose of its interpretation and, more particularly, for determining the scope of the Treaty ratione perso$n a e^{, 52}$ Regarding the 1982 Declaration, it stated that its very purpose was to adapt the original declaration, bringing it in line with the new Nationality Act. It noted that this Declaration had 'not been challenged by the other Member States' which according to the Court of Justice were 'fully aware of its content' leading it to conclude that the Declaration determined the accession conditions accordingly. ${ }^{53}$ Without questioning the nature of the different categories of British citizens, the Court of Justice recognized that the categorisation of British citizens in the UK's Nationality Act reflected that Member State's 'imperial and colonial past', thereby accepting that the rights accorded to British citizens reflected 'the nature of the ties connecting them to the United Kingdom'. ${ }^{54}$ It continued, stating that by 'defin[ing] the United Kingdom nationals who would benefit [...], in particular, from the provisions relating to the free movement of persons', the Declarations clarified 'an issue of particular importance for the other Contracting Parties [...]'. ${ }^{55}$

As observed by Evans, Article 203 TFEU empowers the Council to develop detailed rules and procedures in relation to the Member State's Overseas Countries and Territories. This means that as EU law itself does not appear to require one reading of nationality of a Member State for the purpose of intra-EU mobility, Member States cannot be required to do so either. ${ }^{56}$ Although EU law itself does not oppose to a differentiation between nationals for the purpose of intra-EU mobility, the Court of Justice has been criticised for not seizing the opportunity to redefine the-in essence racist - categorisation of UK citizens in the British Nationality Act, bringing it in line with international standards on race discrimination. ${ }^{57}$ Even if we acknowledge that EU law has to comply with international standards, this criticism misses the point that the Court of Justice is endowed with the task of monitoring and ensuring the observation of EU law. ${ }^{58}$ Its powers do not reach beyond establishing a breach of EU law where national law fails to meet EU standards. Redefining

\footnotetext{
51 Greenwood (1987), pp. 191-192.

52 ECJ 20 February 2001, Case C-192/99, The Queen/Secretary of State for the Home Department, ex parte: Manjit Kaur, ECLI:EU:C:2001:106, para. 24.

53 Ibid., paras. 23 and 26.

54 Ibid., para. 20.

55 Ibid., para. 23.

56 Evans (1991), p. 191.

57 Jessurun d'Oliveira (2010), p. 1031.

58 Art. 19(1) TEU.
} 
the UK's Nationality Act would have gone way beyond its powers, as this is still a national prerogative.

\subsection{Curtailing Member State's Exclusive Competence; The Court of Justice's Case Law}

The Court of Justice might rightly have abstained from redefining the UK's Nationality Act; it has fine-tuned Member State competence in nationality matters, where the contents of intra-EU mobility rights are curtailed as a consequence of a Member State's Nationality Law.

\subsubsection{Individual Withdrawal Decisions}

Nationality as an exclusive Member State competence was recognised and, at the same time, curtailed by the Court of Justice in the Micheletti case as follows: ' $[\mathrm{u}]$ nder international law, it is for each Member State, having due regard to [EU] law, to lay down the conditions for the acquisition and loss of nationality'. ${ }^{59}$ In subsequent rulings that Court has both confirmed the exclusive nature of Member State competence and reiterated the obligation to respect international and EU law when exercising this competence. ${ }^{60}$ Compliance with EU law in individual cases is monitored by both national courts ${ }^{61}$ and the Court of Justice. ${ }^{62}$ The Micheletti case is a prime example of what the Court of Justice has in mind where it instructs Member States to 'hav[e] due regard to [EU] law'. ${ }^{63}$ This case will be discussed in Sect. 3.3.1 as one of the examples illustrating how Member States have responded to the Court of Justice's case law, ring-fencing their exclusive competence in nationality matters.

Eighteen years after the Micheletti ruling, the Court of Justice handed down its ruling in the Rottmann case. This case concerned a decision of the German authorities to withdraw nationality obtained through naturalisation rendering the person concerned stateless. The competence of the Court of Justice to actually hear this case was challenged, for lack of a link with the EU legal order. However, like the referring German court, the Court of Justice considered that the reference was admissible. The Court of Justice reasoned that the withdrawal of Rottmann's German nationality not only rendered him stateless, but also entailed the loss of his

\footnotetext{
59 ECJ 7 July 1992, Case C-369/90, Mario Vicente Micheletti a.O. and Delegación del Gobierno en Cantabria, ECLI:EU:C:1992:295, para. 10. See also: ECJ (Sixth Chamber) 11 November 1999, Case C-179/98, Belgian State/Fatna Mesbah, ECLI:EU:C:1999:549, para. 29; Kaur, above n. 52, para. 19; ECJ (Full Court) 19 October 2004, Case C-200/02, Kunquian Catherine Zhu. Man Lavette Chen/Secretary of State for the Home Department, ECLI:EU:C:200:639, para. 37; Rottmann, above $\mathrm{n}$. 45 , paras. 39 and 45 .

${ }^{60}$ Mesbah, above n. 59, para. 29; Zhu and Chen, above n. 59, para. 37, and Rottmann, above n. 45, para. 39.

61 Rottmann, above n. 45, para. 55. See also: Opinion of Advocate General Mengozzi, in Case C-221/17, MG Tjebbes a.O./Minister of Foreign Affairs, 12 July 2018, ECLI:EU:C:2018:572, para. 47.

62 Rottmann, above n. 45, para. 46.

63 See for the facts: Micheletti, above n. 59, paras. 3-5.
} 
status as an EU citizen as an immediate consequence of the loss of his Member State nationality. ${ }^{64}$

Taking stock of its ruling in the Micheletti case, the Court of Justice first considered whether the German decision to withdraw Rottmann's nationality complied with international standards, more specifically the Convention on the Reduction of Statelessness; the European Convention on Nationality $(\mathrm{ECN})^{65}$; and the Universal Declaration of Human Rights. Rottmann's nationality had been withdrawn because he had failed to share information relevant to his application with the German authorities when making his application for German nationality. The Court of Justice finds in paragraphs 51-53 that according to international standards nationality can be withdrawn even if a person is rendered statelessness, if nationality 'has been acquired by means of misrepresentation or by any other act if fraud', ${ }^{66}$ respectively 'was acquired by means of fraudulent conduct, false information or concealment of any relevant fact attributable to that person'. ${ }^{67}$ As States are permitted under international law to withdraw nationality if this has been acquired by an act of deception, legally established, that act of withdrawal cannot be classed as 'arbitrary'. Therefore, the Court of Justice found that the German authorities' decision to withdraw Rottmann's nationality was in keeping with 'the general principle of international law that no one is arbitrarily to be deprived of his nationality' ${ }^{68}$ After establishing that the withdrawal decision satisfies international standards, the Court of Justice considers whether it is compatible with EU standards.

Even though the loss of German nationality also entails the loss of Rottmann's status as an EU citizen, this is no reason for the Court of Justice to find a breach of EU law, as the decision is in keeping with international standards. However, where loss of nationality also entails the loss of the status of EU citizen, the Court of Justice instructs Member States to ascertain that the withdrawal decision satisfies the principle of proportionality. It provides them with a list of circumstances which they should take into account when withdrawing nationality where that also entails the loss of the status of an EU citizen. ${ }^{69}$

\subsubsection{Amending Nationality Law}

In its reference in the Tjebbes case the Dutch Council of State has requested the Court of Justice to clarify whether the principle of proportionality also applies when a Member State amends its Nationality Law. ${ }^{70}$ In 2003, an amendment to the Dutch

\footnotetext{
64 The facts are taken from paras. 22-32 of the Court of Justice's decision in Rottmann, above n. 45.

65 ETS No. 166 (entry into force 1 March 2000).

66 Art. 8(2) 1961 Convention on the Reduction of Statelessness, concluded at New York on 30 August 1961, entry into force 13 December 1975, UNTS Vol. 989, No. 14458, p. 175.

67 Art. 7(1) and (3) ECN.

68 Art. 15(2) of the Universal Declaration of Human Rights and Art. 4(c) ECN. See: Rottmann, above n. 45 , para. 53.

69 Rottmann, above n. 45, para. 56.

70 Afdeling bestuursrechtspraak Raad van State [Council of State, Judicial Division], 19 April 2017, 201504577/1/A3, 201507057/1/A3, 201508588/1/A3 and 201601993/1/A3, ECLI:NL:RVS:2017:1098, Jurisprudentie Vreemdelingenrecht [Case law Migration law] 2017/124.
} 
Rijkswet op het Nederlanderschap (RWN) ${ }^{71}$ introduced the automatic loss of Dutch nationality after a full 10 years residence outside the EU, completed after reaching the age of majority, i.e. 18 years (Article 15(1)(c) RWN). According to Article 16(1) (d) RWN, a minor shares in his parent's automatic loss of Dutch nationality. Article 15(1)(c) RWN restricts the loss of Dutch nationality to those who are also a national of another State, be it an EU Member State or a third State. Therefore, the status of EU citizen is only lost in the latter case. There are three ways to stall this automatic loss of nationality, meaning that a new 10 year period starts. The first is by taking up habitual residence for at least one full year in this 10 year period in either the Netherlands or an EU Member State. The second is to make a declaration on Dutch nationality. The third is to apply for and actually be issued a Dutch passport or identity card. Article 6(1)(f) RWN provides a fast-track procedure to reacquire Dutch nationality if lost automatically following prolonged residence outside the Netherlands after reaching the age of minority.

When drafting the amendment as it applies to adults, the Dutch legislator took the following instruments of international law into account:

- the 1961 Treaty on the Reduction of Statelessness: loss of Dutch nationality only occurs if there is another nationality thus preventing stateless; and

- Article 7(1)(e) ECN that explicitly sanctions the loss of nationality ex lege or at the initiative of the Contracting Party if there is 'a lack of a genuine link between the State Party and a national habitually residing abroad': 10 years residence outside the EU. ${ }^{72}$

Minors share in the automatic loss of their parent's Dutch nationality, as set out above, unless this renders them stateless. Unlike their parents, they are not provided with legal tools to stall loss of their Dutch nationality. ${ }^{73}$ According to the Dutch authorities this is not necessary as the objective of the rule that applies to minors is to restore and promote the unity of nationality within a family. Loss of nationality is permitted if it serves this purpose under international law, more specifically Article 7(2) ECN and the third recital of the Preamble to the Second Protocol amending the Convention on the Reduction of Cases of Multiple Nationality and Military Obligations in Cases of Multiple Nationality. ${ }^{74}$ The Dutch authorities also claim that loss of nationality if this restores and preserves the unity of nationality within a family is in the child's best interest. ${ }^{75}$

\footnotetext{
71 Rijkswet van 21 December 2000 tot wijziging van de Rijkswet op het Nederlanderschap met betrekking tot de verkrijging, de verlening en het verlies van het Nederlanderschap 2000 [Statute Law of the of the Kingdom of the Netherlands 21 December amending Statute Law of the Kingdom of the Netherlands on the acquisition, granting and loss of Dutch citizenship] 2000, Staatsblad [Dutch Statute Book] 2000, No. 618 (entry into force 1 April 2003).

72 Opinion of the Advocate General Tjebbes, above n. 61, para. 10.

73 Art. 16(1)(d) RWN.

74 ETS No. 149.

75 Opinion of the Advocate General in Tjebbes, above n. 61, para. 124.
} 
At the time of writing the Court of Justice's ruling was not available. Therefore, the following is necessarily based on the Advocate General's Opinion in this case. In general, an Opinion is a good indication of how the Court of Justice will adjudicate, but the latter remains free to rule as it sees fit. Regarding the rule on the automatic loss of Dutch nationality as it applies to adults, the Advocate General finds that the Dutch rule satisfies the obligation to respect both international and EU law, in particular the general principle of proportionality. ${ }^{76}$ This is not, however, the case regarding the automatic loss by minors of their Dutch nationality. The Advocate General recalls that the principle of unity of nationality within the family that international law seeks to preserve is not uncontested, but does not dwell on this point. ${ }^{77}$ Concurring with the Dutch legislator that unity of nationality in a family might serve the best interests of a child, he finds that this is not necessarily always the case. The child's best interests are not served, according to the Advocate General, by preserving the unity of nationality in a family, where the minor's loss of nationality of a Member State also entails the loss of EU citizenship. This is particularly the case if the minor is not provided with special guarantees to stall the loss of his nationality and, in doing so, retain his status as an EU citizen. The reasoning of the Advocate General is that EU citizenship is an autonomous status enjoyed by a minor irrespective of the rights of his parents. Therefore, where the status of EU citizen is lost as an immediate consequence of the loss of Member State nationality, Member States must accord a minor the same procedural and substantive rights as an adult. This is why the Advocate General advice to the Court of Justice is to find that the Dutch rule, as it applies to minors, fails to comply with EU standards. ${ }^{78}$

As said, the Court of Justice is not obliged to follow the Advocate General's opinion. On a general note it is observed that, within the context of EU law, the Court of Justice has already accorded the Convention on the Rights of the Child the status of 'one of the international instruments for the protection of human rights of which it takes account of in applying the general principles of [Union] law', within the meaning of Article 6(3) TEU. ${ }^{79}$ As one of the principles in the EU's Charter on Fundamental Rights, ${ }^{80}$ 'the best interest of the child' has been used by the Court of Justice in its case law to protect minor EU citizens who have not exercised intraEU mobility rights from having to leave the EU because their third-country national primary carer cannot reside in their Member State of nationality, which is discussed in Sect. 3.4 of this contribution. The question is whether it will use the 'best interest of the child' in its ruling, as proposed by the Advocate General, and find that the Dutch rule as it applies to minors is incompatible with EU law because the loss of their autonomous status as an EU citizen is not backed with adequate legal tools to stall this loss.

\footnotetext{
76 Ibid., paras. 46-118.

77 Ibid., para. 123.

78 Ibid., paras. 119-149.

79 ECJ (Grand Chamber) 27 June 2006, Case C-540/03, European Parliament/Council (Family Reunion Directive), ECLI:EU:C:2006:429, para. 37.

${ }^{80}$ Art. 24(2) EU Charter.
} 


\subsection{What Role for Nationality in the EU's Legal Framework?}

Nationality might have been allotted a limited place in the EU Treaty framework, its role as determinant of both EU citizenship and intra-EU mobility rights, including the principle of equal treatment underlying that regime, is far from insignificant. As an exclusive Member State competence, it is the latter that are the gatekeepers to intra-EU mobility rights, not in their capacity of an EU Member State, but rather as sovereign States. ${ }^{81}$ Any amendment introduced by a Member State to its rules on the acquisition and loss of nationality necessarily has repercussions for the other Member States as it is they who are confronted with individual claims to intra-EU mobility meaning that they cannot apply their national immigration rules. Member States appear to have accepted the status quo. This might be because any change would also affect their competence to organise their own Nationality Law as they see fit. Having said this, there is the odd example where they have responded to another Member State's choice in nationality matters, as will be discussed in Sect. 3.2.

The Court of Justice has used its competence to mould Member State competence in nationality matters, by requiring them to observe international and EU standards. It has, however, abstained from imposing any significant restrictions on Member State competence in nationality matters. The international benchmarks identified to date by the Court of Justice in this context are the Treaties on Nationality and on Statelessness. The principle of proportionality, as general principle of EU law is, to date, the EU standard which the Member States have been informed that they must abide by in individual cases. Depending on the outcome of the Tjebbes case, they might also have to pay attention to 'the best interest of the child', as a general principle of EU law. The same case might also extend the obligation to pay due respect to international and EU law when they amend their Nationality Law. ${ }^{82}$ The obligation to treat any individual who presents a document ascertaining that he is a national of another Member State accordingly for the purpose of intra-EU mobility might be the most far-reaching restriction of Member State competence that follows from the Court of Justice's settled case law. ${ }^{83}$ However, this restriction does not strictly speaking concern Member State competence to organise their Nationality Law as they see fit, but rather their competence in immigration matters. Phrased in the terminology of the principle of conferral, it is still the Member State's competence in nationality matters that determines the immigration status of an individual in the other Member State. In doing so, it dictates which immigration rules have to be applied by the other Member States.

\footnotetext{
${ }^{81}$ Staples (1999), p. 78. See on acquisition of nationality of a Member State through naturalisation: http://ec.europa.eu/eurostat/news/themes-in-the-spotlight/citizenship-2016 (accessed 29 October 2018).

${ }^{82}$ See: Opinion of Advocate General in Tjebbes, above n. 61, para. 118.

${ }^{83}$ Micheletti, above n. 59, para. 14.
} 


\section{Cross-Pollination: Nationality Law and Intra-EU Mobility}

\subsection{Introduction}

The examples that are discussed in this section have been selected for one out of two reasons. The first is that it illustrates how Member States and/or an EU institution have responded to an amendment introduced by one of the Member States to its Nationality Law with a view to mitigate the implications of that amendment for their obligations according to the terms of intra-EU mobility. The second is that the example illustrates how a Member State has responded to the Court of Justice's case law on intra-EU mobility as an EU citizen's right by introducing an amendment to its Nationality Law to reduce the impact of that ruling on intra-EU mobility obligations. What the selected examples share, is that unilateral action in the area of nationality affects intra-EU mobility and vice versa and triggers a response by a Member State and/or an EU institution, which then leads to a 'correction' of the imbalance created by the initial actor.

The Immigrant Investment Programmes (IIPs) are an example of the former. They are the subject of Sect. 3.2. The Court of Justice's case law on dual nationality and intra-EU mobility and the position of minors as immigration rights-givers are examples of the latter. They are discussed in respectively Sects. 3.3 and 3.4. All examples will be presented and positioned in the context of intra-EU mobility and nationality. They will be analysed with a view to establish if and if so how the relationship between nationality and intra-EU mobility as an EU citizen's right has been altered and if and if so how the other actors, i.e. Member States and/or EU institutions intervened or responded with a view to restore the original balance.

\subsection{Acquisition of Member State Nationality Through Immigrant Investment Programmes}

Immigrant Investment Programmes were introduced by a number of Member States as a response to their financial difficulties caused by the economic crisis. IIPs are a prime example of unilateral Member State action which can potentially have a strong impact on the number of people who have to be treated as beneficiaries of intra-EU mobility rights by the other Member States. They have been criticized heavily by other Member States and EU institutions alike, challenging their compatibility with EU law.

IIPs share that they aim at attracting financial investments by rich third-country nationals, who are granted facilitated residence rights (so-called Golden Visa Programmes) or fast-track nationality procedures for themselves and their accompanying family members. ${ }^{84}$ The programmes introduced by various Member States differ in terms of the conditions that have to be satisfied by the investor (e.g. the sum of money that has to be invested; how that money has to be invested and in which

${ }^{84}$ Parker (2017), pp. 337-338. 
sector; and the duration of residence in the Member State where the investment is made). ${ }^{85}$ In general, IIPs that give direct access to nationality of a Member State have been heavily criticized for reducing citizenship to a commodity that can be bought by the ultra-rich. As they are only open to the rich, they have been criticized for not respecting the principle of equal treatment. ${ }^{86} \mathrm{~A}$ further point of criticism is that these programmes are a particular stark manifestation of the 'commercialisation of sovereignty' as they transform citizenship into a tradeable commodity. In doing so, IIPs, so it is reasoned, introduce a neoliberal form of belonging into the citizenship discourse that threatens the 'social-contractarian imaginary of citizenship'. ${ }^{87}$

For the purpose of our analysis, however, it is a programme's capacity to provide EU citizenship and/or intra-EU mobility rights to people with no ties with the EU that justifies their consideration. With our knowledge that EU citizenship is accorded to nationals of the Member States and is accompanied by the right to intraEU mobility, the conclusion can only be that fast-track citizenship procedures reach beyond the national legal order. The trade-of between an investment and nationality of a Member State also includes intra-EU mobility rights, as nationality of a Member State is the key to EU citizenship. This means that an investment made in one Member State opens the doors to the EU as a whole and, in doing so, comes with obligations for the other Member States. The effects, in terms of intra-EU mobility entitlements, are less far-reaching in the case of Golden Visa Programmes. These programmes differ from fast-track citizenship programmes as the trade-of is not that between an investment and nationality of a Member State, but rather a right to lawful residence in the Member State where the investment is made. But this is not where the benefits for the investor under a Golden Visa Programme stop. Golden Visa Programmes provide visa-free travel in the Schengen area, which is beneficial to third-country nationals who need a visa to enter and move freely between the Member States. ${ }^{88}$ As Golden Visa Programmes provide lawful residence in a Member State, in the long run (i.e. 5 years), they give access to the status of a long-term resident third-country national. ${ }^{89} \mathrm{With}$ this status comes the right to move and reside in another Member State as provided for by EU law, including the right to work and study. ${ }^{90}$ Lawful residence is also a condition found in Nationality Laws that needs to be satisfied to acquire the nationality of a State through naturalisation. So, even though the implications of Golden Visa Programmes in terms of intra-EU mobility

\footnotetext{
85 On these programmes, see: Carrera (2014), pp. 9-18 and Annex 1; Džankić (2015).

86 Carrera (2014), p. 7; Mavelli (2018), p. 1.

87 Parker (2017), pp. 332-333. See also: Carrera (2014), p. 7; Mavelli (2018), p. 1; and the collection of papers in: Shachar and Bauböck (2014).

88 See on visa obligations: Council Regulation (EC) No. 539/2001 of 15 March 2001 Listing the Third countries whose Nationals must be in Possession of Visas when Crossing the External Borders and those whose Nationals are Exempt from that Requirement [2001] OJ L 81/2.

89 Art. 4(1) Council Directive 2003/109/EC of 25 November 2003 concerning the status of third-country nationals who are long-term residents [2004] OJ L 16/44, amended by: Directive 2011/51/EU of the European Parliament and of the Council of 11 May 2011 amending Council Directive 2003/109/EC to extend its scope to beneficiaries of international protection (further: Directive 2003/109/EC or Longterm Residents Directive) [2011] OJ L 132/1.

90 Art. 14 Directive 2003/109/EC.
} 
are not immediate, in the long run other Member States can be confronted by intraEU mobility claims made by investors under a Golden Visa Programme.

When Malta introduced its IIP in October 2013, it was not the only Member State with a fast-track naturalisation or special residence procedure in exchange for an investment. Ireland had a citizenship by investment programme from 1989-1998, the UK and France granted residence permission following a large investment and in 22 Member States some form of discretionary naturalization was open for those who had contributed towards 'the nation, its culture, sporting or scientific progress or economic success'. ${ }^{91}$ However, it was the Maltese IIP that met with fierce opposition, with the EU's Commission taking the lead. In its initial form, Maltese citizenship could be acquired on donation of $€ 650 \mathrm{k}$ to the Maltese State and supplementary sums for accompanying family members. By the time that the Maltese programme was subject of heated EU debate, it had been amended considerably following internal opposition. ${ }^{92}$ Though the Council acknowledged that Member States have to respect EU law and the principle of mutual trust when they introduce an IIP, it agreed with the Maltese government that, as a general principle of international law, introducing an IIP is a matter of State sovereignty. ${ }^{93}$ The EU's Commission was, however, less considerate. On 15 January 2014, in the plenary session of the European Parliament, Vice-President of the Commission, Vivienne Reding, stated that the link between nationality and EU citizenship imposed an obligation on Member States 'to award citizenship in a spirit of sincere cooperation'. In her opinion this meant that a person's nationality should reflect 'a "genuine link" or "genuine connection" to the country in question'. ${ }^{94}$ She went as far as stating that where 'there is no social fact of attachment [...] between the individual concerned and the State that has naturalized that individual' other Member States could legitimately refuse to recognise nationality acquired through naturalisation where there is no social fact of attachment for the purpose of intra-EU mobility. ${ }^{95}$ The following day, the European Parliament adopted the Resolution on EU Citizenship for Sale, condemning IIPs in general and the Maltese programme in particular. According to the European Parliament, IIPs undermine the very notion of EU citizenship that should not be treated as a tradable commodity, but rather reflect personal ties with the EU, the Member States or an EU citizen. It called on all Member States that had adopted an IIP to bring their law 'in line with the EU's values' ${ }^{96}$ After press coverage that the Commission was considering to instigate an infringement procedure against Malta ${ }^{97}$ and a meeting between the two parties later that month, ${ }^{98}$ the Maltese IIP was amended

\footnotetext{
91 Parker (2017), p. 334.

92 See on these amendments: Carrera (2014), pp. 4-5; Parker (2017), p. 339.

93 Carrera (2014), p. 7.

94 V. Reding, 'Citizenship Must not be up for Sale', European Commission, Speech/14/18, 15 January 2014, available at: http://europa.eu/rapid/press-release_SPEECH-14-18_en.htm.

95 Parker (2017), p. 337. See also: Carrera (2014), pp. 20-21.

96 European Parliament, Resolution on EU Citizenship for Sale, 2013/2995(RSP), 16 January 2014 [2016] OJ C 482/117, nos. 10 and 12-13.

97 Arts. 258 and 260 TFEU.

98 Carrera (2014), pp. 7-8.
} 
on 4 February 2014. Following this amendment, naturalisation by investment was only possible after a compulsory period of residence in Malta of at least 12 months preceding naturalisation.

The Maltese 'citizenship-for-sale' affair is a good example how, in an area of exclusive Member State competence, a Member State can be 'coaxed' into taking the interests of the other Member States into consideration. The example also reveals that the EU has limited tools that it can use to exert pressure on a Member State; namely the principle of sincere cooperation and the EU's values, more specifically respect for a Member State's national identity. ${ }^{99}$

\subsection{Dual Nationality and Intra-EU Mobility}

\subsubsection{Nationality of a Member State and of a Third Country}

The Micheletti case, introduced in Sect. 2.5, is a prime example of what the Court of Justice has in mind where it instructs Member States to 'hav[e] due regard to [Union] law'. Micheletti who was born in Argentina acquired Argentinian nationality through the ius soli principle. As his father was an Italian national, he also acquired Italian nationality at birth through the ius sanguinis principle. In 1989 he lodged an application for a residence permit as a national of a Member State with the Spanish authorities stating that he wished to set up a dentist practice in that Member State. His application was rejected as, according to Article 9 of the Spanish Civil Code, preference had to be given to his Argentinian nationality as prior to his arrival in Spain his country of habitual residence had been Argentina. Giving preference to his Argentinian nationality meant that the Spanish authorities did not have to consider his application for residence as a self-employed person under intra-EU mobility rules, as they only apply to nationals of the Member States. ${ }^{100}$

The Spanish rule was actually in line with the International Court of Justice's ruling in the Nottebohm case. In that case the International Court of Justice found that for the purpose of diplomatic protection a State did not have to recognise a second nationality acquired through naturalisation if there were no genuine ties with that State. ${ }^{101}$ The European Court of Justice does not, however, transpose this reasoning to the EU legal order. According to the latter Court, in the context of intra-EU mobility a third-country national who can provide evidence that he is also a national of a Member State has to be treated according to the rules on intra-EU mobility. This is also the case if he has never resided in the Member State of which he is a national. The classic reasoning, that Member States cannot subject the benefits of intra-EU mobility to conditions not provided for by EU law, is used in paragraph 10. There the Court of Justice reasons that a habitual residence condition cannot be applied where it 'restrict[s] the effects of the grant of the nationality of another

\footnotetext{
99 Art. 4(2) TEU.

100 Currently: Arts. 49-55 TFEU.

101 ICJ Nottebohm case (second phase), Judgment of 6 April 1955, ICJ Reports 1955, p. 4.
} 
Member State'. In paragraph 12 it explains that a 'prior residence condition' could mean that 'the class of persons to whom the [EU] rules on freedom of establishment were applied might vary from one Member State to another'. As intra-EU mobility rules have to be applied uniformly across the EU (supra Sect. 2.1), this would obstruct the very foundations of those rules.

The Spanish authorities responded to the Micheletti ruling by modifying the Treaties on dual nationality which they had concluded with Latin-American States since the 1950s. In their initial form, these bilateral Treaties curtailed the entitlements of the nationals of the Contracting Parties who were a national of both Contracting Parties in the State where they were not habitually resident. The nationality of the State where an individual was not resident was classified as 'dormant' or 'nonactive'. This meant that no rights could be derived, including the right to a passport, from that nationality. By moving to the other Contracting Party, the dual national could 'activate' the previously dormant nationality, which entitled him to a passport issued by the authorities of that State. After being issued with a Spanish passport a dual Latin-American Spaniard could exercise his right to intra-EU mobility. To ensure compliance with the Micheletti ruling, Spain renegotiated its bilateral Treaties with the Latin-American States as follows. By removing the notion of 'dormant' or 'non-active' nationality from those Treaties, Latin-American Spaniards were entitled to a Spanish passport even if they had never resided in Spain. With their Spanish passport they could then exercise their intra-EU mobility rights. To illustrate the impact of these Treaty amendments in terms of the number of Spaniards who had to be treated as beneficiaries of intra-EU mobility rights by the other Member States, the following example suffices. After Spain had amended its Treaty with Argentina, 25.400 Argentineans applied for and obtained a Spanish passport from that Member State's consulate in Buenos Aires in 2001. ${ }^{102}$

In the Micheletti case, the Court of Justice restricts Member State competence to use a 'prior residence condition' to trigger the application of the right to intraEU mobility. The Court of Justice also instructs Member States to treat any person who presents a document attesting that he is a national of a Member State as a beneficiary of intra-EU mobility. Member States cannot refuse that person protection under these rules merely because that person is also a national of a third State. ${ }^{103}$ The lesson to take from the Micheletti case is therefore that Member States cannot subject the right to intra-EU mobility to a prior residence condition. Interestingly, this is precisely what both the EU's Commission and the European Parliament called for in the IIP debate (supra Sect. 3.2). Recapitulating, according to both EU institutions, Member States were entitled to subject intra-EU mobility claims to 'a genuine link based on social attachments to a Member State' condition if Member State nationality had been granted in exchange of an investment.

102 De Groot (2002), pp. 117-120; Margiotta and Vonk (2010), p. 17; Vonk (2006), pp. 187-195.

103 Micheletti, above n. 59, paras. 12-14. 


\subsubsection{Nationality of Two Member States}

The position of EU citizens who are nationals of more than one Member State as beneficiaries of intra-EU mobility rights was first considered by the Court of Justice in 2011. The legal 'obstacle' that the Court of Justice had to deal with was the territorial restriction that applies to the rules on intra-EU mobility. As one of the four freedoms that have to be realised in the context of the Internal Market, intra-EU mobility claims only have to be acknowledged 'in a Member State other than that of which [EU citizens] are a national'. ${ }^{104}$ Article 3(1) of the Residence Directive reflects the necessity of a so-called inter-State link that triggers the operation of the rules on intra-EU mobility (supra Sect. 2.2). The stakes are high, as where there is no 'inter-State link' Member States can apply their own immigration rules. ${ }^{105}$ This is not a problem for the EU citizen himself. He can remain in the State of which he is a national under international law. However, as intra-EU mobility comes with rights for third-country national family members, the territorial restriction in Article 3(1) of the Residence Directive means that an EU citizen cannot invoke intra-EU mobility rights to be reunited with his family members in the Member State of which he is a national. In the two cases that will be discussed in this sub-section the Court of Justice was asked to clarify the position of EU citizens who are nationals of more than one Member State in one of the Member States of which they are a national.

The first case is the Shirley McCarthy case. The dual Irish-British national Shirley McCarthy had lived in the UK for her entire life when she applied for residence permission for her Jamaican spouse as a family member within the meaning of Article 2(2)(a) of the Residence Directive. Before making this application, she had applied for and been issued her first Irish passport. To trigger the application of the Residence Directive she submitted this Irish passport as evidence of her status of an EU citizen resident in a Member State of which she is not a national. Her application made on behalf of her Jamaican spouse to be admitted under the intraEU mobility rules was turned down by the British immigration authorities, stating that her situation was internal to the UK. This meant that her application should be considered under national immigration rules. ${ }^{106}$ The Court of Justice ruled in favour of the Member State, stating in paragraph 39 that 'to move to or reside in', as it is used in Article 3(1) of the Residence Directive, means that a national of a Member State who 'has never exercised his right of free movement and has always resided in a Member State of which he is a national [...] is not covered by the concept of "beneficiary" for the purpose of Article 3(1) of Directive 2004/38/EC [...]'. Regarding nationals of more than one Member State, it observed in paragraph 41 that being a national of more than one Member State 'does not mean that [they have] made use of [their] right of freedom of movement'.

The Lounes case concerns the rules on intra-EU mobility, as amended by the UK authorities following the Shirley McCarthy ruling. It differs from that ruling in the

\footnotetext{
104 Art. 3(1) Directive 2004/38/EC.

105 See on internal situations: Barnard and Peers (2017), pp. 373-374.

106 Shirley McCarthy, above n. 33, paras. 17 and 39.
} 
sense that the EU citizen has exercised free movement rights prior to becoming a national of the Member State where intra-EU mobility rules are invoked. To start, the facts. Ormazabal, a Spanish national, moved to the UK where she first resided as a student and later as a worker, enjoying a right to remain in this period under the Residence Directive. ${ }^{107}$ After 13 years of residence in the UK, she applied for and was granted British citizenship without having to renounce her original, Spanish nationality. As a British citizen she no longer needed the Residence Directive to remain in the UK herself. However, trouble started when, as a national of two Member States, she applied for residence permission under the Residence Directive for her Algerian spouse, Mr Lounes, whom she had met after becoming a British citizen. Her application is turned down by the UK authorities, reasoning that any application made by a British citizen had to be treated as 'internal to the United Kingdom' which meant that it had to be assessed according to British immigration rules. ${ }^{108}$ The Court of Justice finds differently. The mere fact that Ormazabal has resided in what became 'a Member State of which she is a national' through naturalisation, the Court of Justice finds sufficient to remove the label 'purely internal' from her situation. The actual use of intra-EU mobility rights in the past is used by the Court of Justice as justification to differentiate between the rights enjoyed by EU citizens who are dual Member State nationals in a Member State of which they are a national. Key to the Court of Justice's ruling in the Lounes case is that Member States 'cannot restrict the effects that follow from holding the nationality of another Member State, in particular the rights which are attendant thereon under EU law and which are triggered by a citizen exercising his freedom of movement'. ${ }^{109}$ Effectively the Court of Justice introduces a 'prior lawful residence' requirement to protect the EU citizen's entitlement to intra-EU mobility where his nationality places him outside the scope of those rules. 'Lawful' as it is used here means residence according to the Residence Directive.

\subsubsection{Dual Nationality and Intra-EU Mobility Rights}

The picture that emerges from the Court of Justice's case law on dual nationality and intra-EU mobility rights is a mixed one. If a national of a Member State is also a national of a third-country then, with no further ado, all Member States have to treat that person as an EU citizen for the purpose of intra-EU mobility if Member State nationality is attested by a document issued by a Member State. As intra-EU mobility rights cannot be claimed in the Member State of which an EU citizen is a national, these rules do not apply in that Member State. The other Member States are not permitted to require "prior residence in the Member State of which the dual Member State-third-country national holds the nationality' as this would effectively curtail the protection offered by EU law to its citizens.

\footnotetext{
${ }^{107}$ Initially Art. 7(1)(c)—students, then Art. 7(1)(a)—workers, and after 5 years Art. 16(1)—permanent residence of Directive 2004/38/EC.

${ }^{108}$ Lounes, above n. 37, paras. 14-26.

${ }^{109}$ Ibid., para. 55.
} 
As far as EU citizens who are a national of two or more Member States are concerned, the Court of Justice has restricted the operation of the inter-State link condition to the Member State where that EU citizen has only resided as a national of that State, by introducing the condition 'prior residence under the Residence Directive'. In doing this, it has extended the scope of protection offered by intra-EU mobility to include the third-country national family members of EU citizens who become a national of a Member State through naturalisation in one of the Member States of which that EU citizen is a national.

\subsection{Minor EU Citizens and Intra-EU Mobility Rights}

Traditionally in immigration law it is the parent's entitlements that determine the child's position. In 2002 this changed for the EU Member States with the Baumbast ruling. As there is no link with nationality, this string of case law will not be considered here. The second string of case law started with the Court of Justice's ruling in the Chen case. In this decision the Court of Justice acknowledged a minor's autonomous status as an EU citizen which it then used to extend the reading of rightsgivers in intra-EU mobility law to include minors.

Catherine Zhu was born in Northern-Ireland where her Chinese mother had taken up residence shortly before her birth. Her move to Northern-Ireland meant that baby Catherine acquired Irish nationality at birth through the ius soli principle, used in Irish Nationality Law at that time. ${ }^{110}$ As an Irish national baby Catherine was also an EU citizen. After obtaining an Irish passport, baby Catherine moved with her mother to the UK where her mother applied for residence permission under the intra-EU mobility rules for both herself and baby Catherine. The application was turned down by the British immigration authorities, who considered that a child of 8 months was not capable of exercising intra-EU mobility rights. The Court of Justice rejected this contention stating that

[t]he capacity of a national of a Member State to be the holder of rights guaranteed by the Treaty and by secondary law on the free movement of persons cannot be made conditional upon the attainment by the person concerned of the age prescribed for the acquisition of legal capacity to exercise those rights personally. $^{111}$

The British authorities had justified their refusal to apply intra-EU mobility rules to baby Catherine's situation, as, on the facts of the case, they felt that it was quite clear that the very purpose of Catherine's mother's move to Northern-Ireland in the first place was to ensure EU citizenship rights for her child. The move was therefore qualified as 'an attempt improperly to exploit the provisions of [Union]

\footnotetext{
110 Zhu and Chen, above n. 59, para. 11. See also: CJEU (Second Chamber) 10 October 2013, Case C-86/12, Adzo Domenyo Alokpa a.O./Ministre du Travail, de l'Emploi et de l'Immigration, ECLI:EU:C:2013:645, paras. 27-31; CJEU (First Chamber) 30 June 2016, Case C-155/15, Secretary of State for the Home Department/NA, ECLI:EU:C:2016:487, paras. 75-80.

111 Zhu and Chen, above n. 59, para. 20.
} 
law'. This was sufficient reason for them to dismiss the claim to intra-EU mobility. The Court of Justice, however, did not agree with this reasoning as it 'restrict[ed] the effects of the grant of the nationality of another Member State by imposing an additional condition for recognition of that nationality with a view to the exercise of the fundamental freedoms provided for in the Treaty'. ${ }^{112}$ As an EU citizen baby Catherine was entitled to remain in the UK as a beneficiary of intra-EU mobility rights, irrespective of her age and legal capacity. To ensure that her intra-EU mobility right was not deprived of 'any useful effect', her mother, as her primary carer, also enjoyed a right to remain in that Member State, subject to the condition that the residence requirements in the Residence Directive were satisfied. A broad reading of the 'sufficient financial means requirement' meant that as her mother could provide financially for baby Catherine, both enjoyed a right to remain in the UK under the Residence Directive. ${ }^{113}$

The Chen string of case law imposes an obligation on the so-called host Member State to treat minors from the other Member States as an EU citizen with the accompanying right to intra-EU mobility, thereby protecting both the minor and the caring parent. The Ruiz Zambrano string of case law does the same albeit in the Member State of which the minor is a national. The reasoning of the Court of Justice in the Ruiz Zambrano case is that minor EU citizens are effectively 'depriv[ed] [...] of the genuine enjoyment of the substance of the rights conferred by virtue of their status as citizens of the Union' if their primary carer cannot reside with them in the Member State of which they are a national. ${ }^{114}$ The assumption is that minor EU citizens 'would have to leave the territory of the Union in order to accompany their parents' if the latter do not enjoy lawful residence in the minor's Member State of nationality. If this is the minor's fate then he is 'unable to exercise the substance of the rights conferred on them by virtue of their status as citizens of the Union'. ${ }^{115}$

It is the autonomous nature of the status of EU citizenship that the Court of Justice uses to frame an obligation for Member States to treat minors who are EU citizens as EU citizens. The only avenue open to Member States wishing to contain the implications of these judgements, was to amend their Nationality Law. This is precisely what happened in Ireland (Chen) and Belgium (Ruiz Zambrano). The Irish legislature was already considering an amendment of its Nationality Law at the time of the Chen ruling, as Ms Chen was not the only mother who had moved to Ireland where she give birth to her child, inspired by the easy access to EU citizenship and the right to intra-EU mobility. The loophole that had provided easy access to EU citizenship and intra-EU mobility was closed by the Irish legislator. Following an amendment to the law acquisition of Irish nationality through birth in that country is subject to an additional condition concerning a parent's lawful residence status in

\footnotetext{
112 Ibid., paras. 39-40. With reference to: Micheletti, above n. 59, para. 10; ECJ 2 October 2003, Case C-148/02, Carlos Garcia Avello and État belge, ECLI:EU:C:2003:539, para. 28.

113 Zhu and Chen, above n. 59, para. 45.

114 CJ EU (Grand Chamber) 8 March 2011, Case C-34/99, Gerardo Ruiz Zambrano/Office national de l'emploi (ONEm), ECLI:EU:C:2011:124, para. 42.

115 Ibid., para. 44.
} 
that State. ${ }^{116}$ In the Ruiz Zambrano case, the two children who were born in Belgium had not been registered by their Columbian parents with the Colombian authorities. To protect them from statelessness, they acquired Belgium nationality ex lege. The Belgium response to the Court of Justice's ruling in the Ruiz Zambrano case was to amend the rules on acquisition of Belgium nationality, which were designed specifically to protect children born in that Member State from becoming stateless as follows. If the child's statelessness was a direct consequence of a failure on behalf of the parents to take the necessary steps to register the child with the diplomatic or consular authorities of the State of which the child is entitled to its nationality through the ius sanguinis principle, then that child is not entitled to Belgium nationality ex lege merely because he was born in that Member State. ${ }^{117}$

\subsection{Nationality, EU Citizenship and Intra-EU Mobility: Have the Scales Tipped?}

Do the examples discussed in this section justify the conclusion that the introduction of EU citizenship has affected Member State competence in nationality matters, because it is the key to EU citizenship and intra-EU mobility?

A first observation is that the Court of Justice's findings in the Micheletti case have not been overruled. Member State competence in nationality matters is still recognised as exclusive by nature meaning that Member States can still determine the conditions for acquisition and loss of their nationality as long as they respect international and EU standards. For the purpose of intra-EU mobility claims, Member States cannot subject the enjoyment of this right to additional conditions, for instance prior residence in the Member State of nationality. Where evidence of Member State nationality is produced Member States cannot question whether that person is a national of a Member State, but have to treat him as an EU citizen who is entitled to intra-EU mobility.

A second observation concerns intra-EU mobility rights where the EU citizen is a national of more than one State. The picture that emerges is contradictory, but might be reconciled if we consider the rulings of the Court of Justice discussed in this section as an attempt to uphold the effectiveness of intra-EU mobility rights. Considering the cases from an individual's perspective, the Court of Justice finds fault in imposing a residence condition if, as a result, the protection offered by the rules on intra-EU mobility to an individual is reduced. This would be the situation if an EU citizen who is both a national of a Member State and a third-country national could only rely on the protection of intra-EU mobility rights after taking up residence in the Member State of which he is a national. The reverse situation is that of the EU citizen who is a national of two Member States. By introducing a 'prior residence requirement' that EU citizen is not barred from invoking intra-EU mobility rights in one of the Member States of which he is a national. Thus the territorial scope of intra-EU mobility only applies in the Member State

\footnotetext{
116 Rostek and Davies (2006), para. 3.3; Ryan (2004); Tryfinidou (2005), p. 531. See on Nationality Laws across the globe: http://globalcit.eu/acquisition-citizenship/ (accessed 5 November 2018).

117 Chun Luk (2018), p. 310.
} 
of his original nationality as he has never resided in that Member State under the Residence Directive. This puts the EU citizen who is a national of more than one Member State by naturalization in the same position as an EU citizen with one nationality.

The third observation is that Member States do consider their obligations under EU law when dealing with nationality matters. Admittedly, the Maltese government needed some coaxing to remove the sharp edges from its IIP. The information provided by the Dutch government in the pending Tjebbes case, however, reveals that they did consider international and EU standards, before they introduced the rule on automatic loss of Dutch nationality after 10 years of residence outside the EU.

The forth observation is that a broad reading by the Court of Justice of intraEU mobility entitlements, is a reason for Member States to amend their Nationality Law making it less easy to become a beneficiary of those entitlements, as was the case following both the Chen and Ruiz Zambrano case. By introducing an ius sanguinis condition to supplement the ius soli principle in the case of Irish nationality and by stipulating that statelessness as a result of the failure of parents to register a child with the authorities does not entitle a child to Belgium nationality.

In general, these observations merit the conclusion that the fact that nationality has remained an exclusive Member State competence does not mean that they can arrange their Nationality Laws as they see fit. There might be no competence for the EU legislator to legislate on nationality, but the fact that nationality of a Member State entitles that person to intra-EU mobility has made them sensitive to developments in other Member States and interventions by EU institutions, including the Court of Justice, when dealing with nationality matters. The examples discussed in this section reveal that the very link between intra-EU mobility and nationality has triggered an informal harmonisation process. Ironically, where Member States are not willing to confer powers on the EU to adopt harmonisation measures in the field of nationality, it is developments in an area of shared competence that are actually bringing the conditions for acquisition and loss of nationality in the different Member States closer together. Thus there is no Member State that still uses a strict ius soli rule in its Nationality Law. This gradual, informal process of harmonisation, in my opinion, does not merit the conclusion that there has been a significant erosion of the exclusive nature of Member State competence in nationality matters that can be attributed directly to the introduction of EU citizenship. This certainly holds true if the Court of Justice follows its Advocate General's Opinion in the Tjebbes case. Rather than eroding the exclusive nature of Member State competence in nationality matters, this case will consolidate that Court's findings in the Micheletti and Rottmann cases, extending the findings in those cases to the level of legislation. Where Member State competence is being eroded, is in immigration matters. This is not new, as the Court of Justice has always been an advocate of a broad reading of intraEU mobility rights. What is new is that Member States have responded to the Court of Justice's broad reading of intra-EU mobility rights by introducing an amendment to their Nationality Law thereby making it more difficult to acquire the nationality of a Member State and, in its slipstream, benefit from the right to intra-EU mobility. 


\section{Withdrawal of a Member State: Time to Reconsider the Role of Nationality in EU Law}

The question whether Member State nationality should be the sole condition to qualify as EU citizen has been questioned in the past for its exclusion of third-country nationals who have resided in an EU Member State over a longer period, but do not enjoy the same rights as EU citizens. Suggestions to amend the definition of EU citizen by introducing a second route to acquire this status, i.e. a lawful residence requirement, have not resulted in a new definition of EU citizen. ${ }^{118}$ These suggestions would not, however, provide an adequate solution for the challenge that is now facing the EU with the upcoming withdrawal of one of its Member States, the UK. Withdrawal of EU membership was unconceivable at the time when EU citizenship was introduced. Therefore no consideration was given either to the position of EU citizens or to their accompanying rights post-withdrawal.

As long as the only condition to acquire the status of EU citizen is nationality of a Member State, a Member State's withdrawal from the EU means that the nationals of that Member State, at the time of writing the UK, lose both their status as an EU citizen and their right to intra-EU mobility. Withdrawal means that when a Member State leaves the EU, its nationals no longer qualify as 'national of a Member State'. If no agreement is reached, their right to reside in the remaining 27 Member States will have to be determined in accordance with the rules that apply to thirdcountry nationals. The implications of a withdrawal in terms of intra-EU mobility do not stop her. Although there is no loss of EU citizenship, the nationals of the remaining 27 Member States can no longer rely on their status as an EU citizen in the withdrawing Member State. If they wish to remain in the withdrawing Member State, they will have to qualify for residence under the withdrawing Member State's national immigration rules.

As the Treaties remain silent on the rights of EU citizens post-withdrawal, this is one of the many issues that had to be provided for in the withdrawal negotiations between the EU and the UK. At the time of writing, intra-EU mobility after the UK's withdrawal is the subject of Part Two of the Draft Agreement on the withdrawal of the United Kingdom of Great Britain and Northern Ireland from the European Union and the European Atomic Energy Community of 15 March 2018 that is entitled Citizens Rights. ${ }^{119}$ Essentially, the Draft Agreement freezes the situation as it is at the moment of the UK's withdrawal. It preserves existing intra-EU mobility rights in the host State, be it the withdrawing or a remaining Member State, at the end of the transition period for the beneficiary's entire life, subject to the following caveats. ${ }^{120}$ The rights enjoyed at the end of the transition period by UK citizens in

\footnotetext{
118 See: Becker (2004); García Andrade (2014); Iglesias Sánchez (2013); Kostakopoulou (2009); O'Keeffe (1994); Preuss (1995); Shaw (1997); Staples (1999), pp. 335-355; Soysal (1995).

119 TF50 (2018) 33/2, Commission to UK (further: Draft Agreement), https://ec.europa.eu/commission/ sites/beta-political/files/negotiation-agreements-atom-energy-15mar_en.pdf (accessed 27 July 2018).

120 Art. 35 Draft Agreement. See for the family members who benefit from the special withdrawal regime: Art. 9(1)(e) and (2)-(5) Draft Agreement.
} 
their host Member State cannot be transferred to one of the other remaining Member States. ${ }^{121}$ The right to permanent residence is lost forever after five consecutive years of absence from the original host State. ${ }^{122}$ Thus, UK citizens and their family members exercising their right to intra-EU mobility will be able to continue their residence in their host Member State under the same conditions as applied up and until the end of a transition period. Nationals of the 27 remaining Member States and their family members who are residents of the UK at the end of the transition period can stay in the UK under the same conditions as they were used to. Protection includes family members who have not satisfied the obligatory time limits at the time that the transition period expires. ${ }^{123}$ Close reading, however, reveals that the authorities may restrict the right to reside, if after the transition period has ended a beneficiary's conduct is a reason for concerns related to public policy and national security 'as provided for by national law [emphasis added]', as opposed to EU standards. ${ }^{124}$

There are valid reasons to find fault with these arrangements. However, preserving existing rights might be 'better than nothing'. Maybe we should accept that it is too much to expect parties in a divorce procedure to put EU citizens on the first place. To protect EU citizens from becoming yet again a pawn on the chessboard in future withdrawal negotiations, the idea of redefining who qualifies as an EU citizen and what happens to their rights post-withdrawal should be given serious consideration outside the context of withdrawal negotiations. It is acknowledged that redefining EU citizenship by adding a residence condition will be a solution for the citizens of the withdrawing Member State if they have resided in one of the remaining Member State as an EU citizen prior to the withdrawal of the State of which they are a national. Their past residence-if sufficiently long-would secure them the status of EU citizen with the accompanying intra-EU mobility right post-withdrawal. Nationals of the withdrawing Member State who move to an EU Member State postwithdrawal can, as a third-country national, acquire the status of EU citizen by satisfying the residence condition. For nationals of the remaining Member States this is not however a solution. Under the terms of Article 50 of the EU Treaty, withdrawal means that the Treaties stop to have effect in the departing Member State. If the Treaties cease to apply, then - as a Treaty based status - the status as an EU citizenship is of no avail to them in the departing Member State. An alternative solution is necessary to protect the EU citizenship rights of nationals of the remaining Member States in the withdrawing Member State.

It is in the context of Article 50 TEU that the true implications of defining EU citizenship in terms of nationality of a Member States are revealed. If we want to protect EU citizens against waking up 1 day in the future in the knowledge that the rights that were self-evident yesterday, no longer exist today, then the lesson to take from the Brexit is that EU citizenship needs to be redefined in terms of belonging.

\footnotetext{
121 Art. 32 Draft Agreement.

122 Art. 14(3) Draft Agreement.

123 Arts. 12-15 Draft Agreement.

124 Art. 18(1)-(2) Draft Agreement.
} 
Yes, this will shift the competence balance in favour of the EU as the Member States will no longer be the sole gatekeepers to EU citizenship. However, adding a second condition to determine who qualifies as an EU citizen does not have to affect the exclusive nature of Member State competence to define who its nationals are. If sharing competence is the price to pay, does this matter if this brings Europe closer to its citizens?

Open Access This article is distributed under the terms of the Creative Commons Attribution 4.0 International License (http://creativecommons.org/licenses/by/4.0/), which permits unrestricted use, distribution, and reproduction in any medium, provided you give appropriate credit to the original author(s) and the source, provide a link to the Creative Commons license, and indicate if changes were made.

\section{References}

Barnard C, Peers S (2017) European Union law. OUP, Oxford

Becker MA (2004) Managing diversity in the European Union: inclusive European citizenship and thirdcountry nationals. Yale Hum Rights Dev Law J 7:132-183

Carrera S (2014) How much does EU citizenship cost? The Maltese citizenship-for-sale affair: a breakthrough for sincere cooperation in citizenship of the union? In: CEPS paper in liberty and security in Europe, no. 64/April 2014

Chun Luk N (2018) Over de groeiende invloed van Unieburgerschap op het nationaliteitsrecht van lidstaten. Asiel Migrantenrecht 9:307-313

Closa C (1994) Citizenship of the Union and nationality of Member States. In: O'Keeffe D, Twomey PM (eds) Legal issues of the Maastricht Treaty. Chancery Law Publishing, London, pp 109-119

De Groot G-R (2002) Latin-American citizens: some consequences of the autonomy of the Member States of the European Union in nationality matters. Maastricht J Eur Comp Law 9:115-120

De Groot G-R (2004) Towards a European nationality law. Electron J Comp Law 8(3):1-37

Džankić J (2015) Investment-based citizenship and residence programmes in the EU. Robert Schuman Centre for Advanced Studies, EUDO Citizenship Observatory. In: EUI working papers, RSCAS 2015/08. http://cadmus.eui.eu/bitstream/handle/1814/34484/RSCAS_2015_08.pdf?sequence=1. Accessed 5 Nov 2018

Evans A (1991) Nationality law and European integration. Eur Law Rev 16:190-215

Evans A, Jessurun D'Oliveira H-U (1991) Nationality and citizenship. In: Cassese A, Claphamm A, Weiler J (eds) Human rights and the European community: methods of protection. Nomos Verlagsgesellschaft, Baden-Baden, pp 299-350

García Andrade P (2014) Privileged third-country nationals and their right to free movement and residence to and in the EU: question of status and competence. In: Guild E, Gortázar-Rotaeche CJ, Kostakopoulou D (eds) The reconceptualization of European Union citizenship. Nijhoff, Brill, pp $111-131$

Greenwood Ch (1987) Nationality and the limits of the free movement of persons in community law. Yearb Eur Law 7:185-210. https://www.ceps.eu/system/files/LSE\%20No\%2064\%20Price\%20of\%20 EU\%20Citizenship\%20final2.pdf. Accessed 5 Nov 2018

Iglesias Sánchez S (2013) Fundamental rights protection for third country nationals and citizens of the Union: principles for enhancing coherence. Eur J Migr Law 15:137-153

Jessurun d'Oliveira HU (1999) Nationality and the European Union after Amsterdam. In: O'Keeffe D, Twomey P (eds) Legal issues of the Amsterdam Treaty. Hart Publishing, Oxford/Portland, pp 395-412

Jessurun d'Oliveira HU (2010) Ontkoppeling van nationaliteit en Unieburgerschap? Opmerkingen over de Rottmann-zaak. Nederlands Juristenblad 86:1028-1033

Kochenov D (2014) EU citizenship without duties. Eur Law J 20:482-498

Kostakopoulou D (2009) Citizenship goes public: the institutional design of a national citizenship. J Polit Philos 17:275-306 
Margiotta C, Vonk O (2010) Nationality law and European citizenship; the role of dual nationality. In: EUI working papers, RSCAS 2010/66. Robert Schumann Centre for Advanced Studies, EUDO Citizenship Observatory. http://cadmus.eui.eu/bitstream/handle/1814/14623/RSCAS_2010_66.corr. pdf? sequence $=3$. Accessed 5 Nov 2018

Mavelli L (2018) Citizenship for sale and the neoliberal political economy of belonging. Int Stud Q 2018:1-12

Nic Shuibhne N (2013) The coherence of EU free movement law. Constitutional responsibility and the Court of Justice. In: Oxford studies in European law. Oxford University Press, Oxford

Nic Shuibhne N (2015) Limits rising, duties ascending: the changing legal shape of union citizenship. Common Market Law Rev 53:889-938

O'Keeffe D (1994) Union citizenship. In: O'Keeffe D, Twomey P (eds) Legal issues of the Maastricht treaty. Chancery Law Publishers, London, pp 87-107

O'Leary S (1992) Nationality law and community citizenship: a tale of two uneasy bedfellows. Yearb Eur Law 12:353-384

Oosterom-Staples H, Vazquez-Munoz A (2004) Burgerschap van de Unie. Soc Econ Wetgeving 52:494-506

Parker O (2017) Commercializing citizenship in crisis EU: the case of immigrant investor programmes. J Common Market Stud 55:332-348

Preuss U (1995) Problems of a concept of European citizenship. Polit Stud 44:534-552

Raucea C (2016) European citizenship and the right to reside: "no one on the outside has a right to be inside?'. Eur Law J 22:470-491

Rostek K, Davies G (2006) The impact of Union citizenship on national citizenship policies. In: European integration online papers 10(5). http://eiop.or.at/eiop/pdf/2006-005.pdf. Accessed 5 Nov 2018

Ryan B (2004) The Celtic cubs: the controversy over birth right citizenship in Ireland. Eur J Migr Law 6:173-193

Shachar A, Bauböck R (2014) Should citizenship be for sale? Robert Schuman Centre for Advanced Studies, EUDO Citizenship Observatory. In: EUI working papers, RSCAS 2014/01. http://cadmu s.eui.eu/bitstream/handle/1814/29318/RSCAS_2014_01.pdf?sequence=1. Accessed 5 Nov 2018

Shaw J (1997) The many pasts and futures of citizenship of the EU. Eur Law Rev 22:554-572

Soysal NY (1995) Limits of citizenship: migrants and post-national membership in Europe. University of Chicago Press, Chicago

Staples H (1999) The legal status of third country nationals in the European Union. European monographs no. 22. Kluwer Law International, The Hague

Tryfonidou A (2005) C-200/02, Kunqian Catherine Zhu and Man Lavette Chen v. Secretary of State for the Home Department: further cracks in the 'Great Wall' of the European Union? Eur Public Law 11:527-541

Vonk O (2006) Latijns-Amerikaanse Spanjaarden en het Europees burgerschap. Migrantenrecht 5:187-195 